\title{
Rainwater harvesting in urban areas of developed countries. The state of the art (1980-2017)
}

\section{Alvaro-Francisco Morote*}

Department of Didactics of Experimental and Social Sciences,

Faculty of Teaching,

University of Valencia,

Avda Tarongers 4, 46022 Valencia,

Apartado de Correos 22045, Spain

Email: alvaro.morote@uv.es

*Corresponding author

\section{María Hernández}

Department of Regional Geographic Analysis and Physical Geography, University of Alicante,

Carretera de Sant Vicent del Raspeig, s/n - 03080, Alicante, Spain

Email: maria.hernandez@ua.es

\section{Saeid Eslamian}

Department of Water Engineering,

Isfahan University of Technology,

Isfahan, Iran

Email: prof.s.eslamian@gmail.com

\begin{abstract}
Many urban areas suffer from water scarcity although paradoxically, a local source such as rainwater is mostly treated as a risk rather than a valuable resource. This change of paradigm is included in the 'integrated water resources management' and 'demand management' approach. The aim of this research is to identify and analyse studies that explore subject matters concerning rainwater in the integrated management systems of water resources into developed countries. The research methodology consisted in a literature review (from the 1980s to 2017) of territorial studies that examine rainwater harvesting in urban areas of the developed countries. To this end, a bibliometric analysis has been carried out in different databases according to the definition of keywords. The results reveal five thematic areas were identified and temporal and spatial differences between some subject matters.
\end{abstract}

Keywords: rainwater; harvesting; integrated water resources; management; developed countries.

Reference to this paper should be made as follows: Morote, A-F., Hernández, M. and Eslamian, S. (2020) 'Rainwater harvesting in urban areas of developed countries. The state of the art (1980-2017)', Int. J. Hydrology Science and Technology, Vol. 10, No. 5, pp.448-470. 
Biographical notes: Alvaro-Francisco Morote is a Lecturer at the Department of Didactics of Experimental and Social Sciences at University of Valencia, Spain. His research interests include studies about water consumption, the urbanisation process, the study about the relation about new urban natures (gardens and pools) with water demand, natural hazards and the didactic of geography.

María Hernández is a Full Professor of Geography in the Department of Regional Geographic Analysis and Physical Geography at University of Alicante. Her research interests, initiated in 1994, are focused on studies on analysis and evolution of rural and cultural landscapes, agriculture and rural development, tourism and local development, land management, demand and water uses and natural hazards.

Saeid Eslamian is a Full Professor of Water System Engineering in the Department of Water Engineering at Isfahan University of Technology, Iran, where he was been since 1995. His research focuses mainly on water resources planning, management and sustainability, and statistical and environment hydrological in a changing climate.

\section{Introduction}

Water management plays a major role in the functioning of urban areas, but applying alternative strategies might be more or less effective depending on the urban form and water demand (Petit-Boix et al., 2018). Urban water demand is expected to increase drastically worldwide in the next decades. Furthermore, climate change is likely to increase the variability of precipitation and the number of flood and drought episodes (Alamdari et al., 2018; Ennenbach et al., 2018; Musayev et al., 2018; IPCC, 2018). As a result of an increasing number of drought periods (partially exacerbated by climate change and changing patterns in water consumption), non-conventional water resources are becoming increasingly more popular (Bashar et al., 2018; Grant et al., 2018; Xu et al., 2018). These trends accentuate the need to adapt water management to new and challenging environmental and socio-economic conditions (Morote and Hernández, 2017).

The so-called 'demand management' approach must be assessed within the scope of the broader 'integrated water resources management' (IWRM). In it, supply and demand measures are combined to produce efficient mixtures aimed at decreasing the ever growing urban need for freshwater (Stephenson, 1999). According to the IWRM philosophy, previously ignored water resources within the urban cycle are being rediscovered under the concept of 'fit for purpose' (Brown et al., 2009). That it is to say the assumption that water has many qualities and not all water uses (urban, industrial, agricultural, environmental and recreational) require the same quality. The IWRM approach and water resources such as rainwater, treated wastewater and greywater also herald new forms of governance and control of the urban water cycle (Sedlak, 2014).

Cities have depended on reliable water sources for their expansion while urbanisation has enormously modified local, regional and even national water cycles (Vallès-Casas et al., 2016). Over the last decade, there has been a growing interest in innovative stormwater management practices, thus breaking away from conventional 'end of pipe' 
approaches (based on conveying water offsite to centralised detention facilities). Innovative strategies, referred to as sustainable urban drainage systems (SUDS), low impact development (LID) or green infrastructures have therefore become popular among practitioners and the public authorities. However, while the need to control pollution is generally well-accepted, there is no widespread agreement about what type of management criteria should be established for developers (Sage et al., 2015).

In the last decades, in urban areas of the developed world, rainwater harvesting (RWH) has emerged as a field of sustainable water management, which offers an alternative water supply for at least non-drinking uses (Kandasamy et al., 2016; Imteaz and Moniruzzaman, 2018). Among all the alternative options to minimise drinking water demand, RWH system has received a high level of attention due to its easy collection and reuse potentials (Paudel et al., 2018). These alternative resources have very different characteristics (Domènech et al., 2013). Some of them (i.e., RWH) are millennia-old, while others (i.e., treated wastewater and greywater recycling) have caught on as a result of technological progress (Vallès-Casas et al., 2016). RWH is now increasingly used to manage urban flood and alleviate water scarcity crisis (Jing et al., 2017). RWH systems represent a promising alternative to increase flexibility and robustness of water supply systems (Lopes et al., 2017). And it may supply daily non-drinking water for irrigation, toilette flushing, car washing and other uses (Ursino and Grisi, 2017).

The use of rainwater for urban uses is practiced in many developed countries to mitigate water scarcity in urban environments (López-Zavala et al., 2016; Fisher-Jeffes et al., 2017; Li et al., 2017), but it has been also adopted in developing countries. RWH is a widely known and used technique in Africa and Asia, especially, in China (Jing et al., 2017).

According to Sitzenfrei et al. (2013), to meet upcoming challenges such as climate change, the rapid growth and shrinking of cities and water scarcity, water infrastructure needs to be more flexible, adaptable and sustainable [e.g., SUDS, water sensitive urban design (WSUD)]. WSUD is a planning and design philosophy used to minimise the hydrological impacts of urban development on the surrounding environment (Morison and Brown, 2011; Okhravi et al., 2014, 2015; Rahman et al., 2017). It is an integrated water management system that encompasses LID, water conservation and recycling, water quality management, and urban ecology (Donofrio et al., 2009). According to Saunders and Peirson (2013), WSUD provides an effective method of improving discharge water quality, providing water storage capacity and achieving peak flow attenuation.

The aim of this research is:

1 To identify studies that explore the use and management of rainwater in urban areas of the developed world (1980-2017).

2 To identify possible gaps in research that would help to advance RHW in future.

This is relevant considering the initial hypothesis of this research work. The hypothesis is that using rainwater will become increasingly more important in the planning and integrated management of water resources in the developed countries.

The structure of this study is briefly described hereinafter. In the introduction, the potential for the use and management of rainwater in urban environments is discussed, taking into account that it has traditionally been a 'forgotten' resource in cities of the 
developed world. After the introduction, the methodology and the results are described. Finally, the paper ends with the 'discussion' and 'conclusions' sections.

\section{Methodology}

The research methodology consisted in literature review (from the 1980s to 2017) of the territorial studies (research articles from the 'social sciences') that examine the use, the harvested options and the management of rainwater in the urban areas in the developed countries. It is analysed this period due to the lack of studies before this date.

To this end, a literature search (in English) was organised using databases such as 'Scopus', 'Scimago' and the 'Web of Science Core Collection'. The search terms selected were keywords related to the new principles of integrated management of water resources, demand management or the incorporation of rainwater in the water cycle of the cities. To be precise, the words were: rainwater, stormwater, RWH, urban drainage management, WSUD, fit for purpose, storm reservoir, water saving ordinance, greenroofs and sponge cities.

The choice of the study area (developed countries) is determined as the main search criteria (social sciences) by the objectives of the research. In this case, the socio-economic differences, of urban development, regulatory framework or predominance of water urban use (as opposed to farming uses) determined that the developed countries were chosen as the study area and exclude the underdeveloped. This does not mean that in the latter ones there are no studies on this subject. The remarkable achievement of paper on 'sponge city' in China or those carried out in Brazil or India in rural areas, for instance, evidences the interest on these issues outside the developed countries. However, their objectives (agricultural purpose) or incorporation of these techniques in fast and ex-novo urbanisation processes excluded them from the objectives of this research (analysis of harvesting systems and use of rainwater in urban areas where urbanisation is a well-established process). Regarding the countries, to determine which countries are considered as developed the criterion established by the OECD has been used.

The main search criteria used was to analyse the references that appear under the heading 'social sciences', namely, to show how the rainwater systems have been analysed from a territorial approach. That it is to say, widespread distribution of these techniques and predominance of one or another depending on the characteristic of territories concerned. Reasons for its choice were that:

1 Determining the relationships between territorial scope and predominant themes was one of the objectives of this paper.

2 The structure of the database carried out searches in large blocks of contents such as social sciences, engineering, health, etc.

3 Social sciences include disciplines such as geography, economics, sociology or law, with very diverse areas of knowledge.

The linkage with the territory is the defining element of one of them, the geography. This will allow highlighting the interaction and implementation of these systems (planning, management, rules, etc.), in a specific area (study area) and the potential repercussions 
(increase of available water resources, reducing of flood risk, etc.). In a first step, references were sought that contained the above-named keywords. At the same time, another search was made under the heading 'engineering' (secondary criteria) to identify publications on this subject and with the same keywords as search engines.

Adding the result of both criteria, a list of references, where geographic, economic, social, environmental or engineering issues are interrelated, were obtained. A series of filters were applied to the results obtained in this first phase (22,571 articles). The first of these filters combined various simple terms using the connectors 'and' and 'or' to cut down on the references that considered relative issues. For example, the word 'rain', although they were not directly related to its use as a water resource, repeated references were eliminated as well. The total number of items obtained in this second search was 2,185 . The interrelated terms and the resulting items were: urban drainage and rainwater (269 papers), purpose and RWH (110 papers), RWH (943 papers), storm tank and rainwater (49 papers), saving and rainwater (97 papers), greenroofs (413 papers), WSUDs (179 papers) and sponge cities (125 papers).

A third filter was applied to the results obtained in the second phase (2,185 references) to eliminate references that concerned $\mathrm{RWH}$, but they did not focus on rainwater in urban areas with territorial purpose or incidence in a specific geographic area. The importance given to a specific study area (that is to say, a city or country) is determined by the geographical analysis, one of the objectives of this study, and by doing so be able to carry out the analysis on the state of affairs according to the areas. Consequently, studies that examined issues from purely a chemical, biological-environmental point of view or where the modelling predominated were excluded. In turn, using rainwater for agricultural purposes was excluded. The reading of the abstracts and checking scopes and matters on the webpages of the journals where the paper were published were the filters used in this phase. Finally, the total number of studies was 394. In this last phase, the abstracts and papers were consulted to identify their methodology and results. And from this, to assign the papers to each of the thematic lines in which the publications have been grouped. That is to say, not only the number of paper was analysed (which allowed us to identify the predominance of some lines or others and their temporary and geographical distribution), but also the contents, identifying work methods, subject analysed, etc.).

The results were grouped into five large topics of research attending to the purpose of the use of rainwater:

1 floods and sustainable urban drainage

2 rainwater and pollution

3 means of storing rainwater

4 greenroofs and rainwater

5 the potential of using rainwater and the resulting savings.

Besides, due to the big number of the works and authors, only the authors that were cited in the text were incorporated in the references section. Within each of these sections, the spatial and temporal distributions of the papers were also analysed. The chronological evolution of the topics allows showing how these publications have evolved over time and the appearance of new ones. Regarding the location (spatial variable), analysing it allow highlighting the interaction and implementation of these systems in a specific area 
(planning, management, norms, etc.), the potential repercussions (increase of available water resources, reducing of flood risk, etc.), and relationships between socioeconomic and environmental characteristics and the predominance of some lines of research.

\section{Results}

The papers identified regarding rainwater and its management for later use in cities of developed countries shows that there are five lines of research. Of these, two stand out over the rest: 'floods and sustainable urban drainage' (122 papers, 30.96\%) and 'potential of using rainwater and the resulting savings' (134 papers, 34.01\%) (Figure 1). Providing a global analysis of the evolution of the research studies identified, it should be noted:

1 In the ' 80 s and ' 90 s of the last century, some of the first papers were found (Krejci and Gujer, 1985).

2 It is from the middle of the first decade of the 2000s and, especially, from 2010 when the interest of the management and the use of rainwater in urban areas receives most attention (Figure 2).

In fact, the $66.49 \%$ of all studies identified are from 2011-2017 (262 papers).

Figure 1 Number of papers identified according to the subject matters

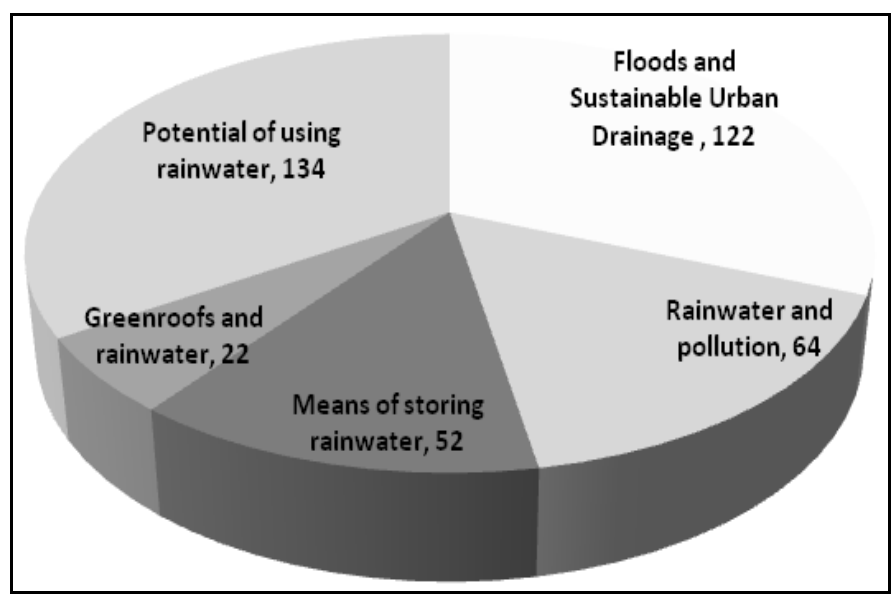

The arguments supporting the interest in these topics are:

1 The large urban growths that have generated the waterproofing of large percentages of land and the use of floodprone areas.

2 Environmental problems related to soil and water pollution.

3 The development of rainwater storage technologies for their drainage, treatment or use.

4 A growing interest in the use of rainwater as an alternative resource due to episodes of water shortage as a result of the increased demand and the effects of climate change (greater intensity and frequency of droughts). 
These topics show that rainwater is a research lines that relates and identifies urban crises and environmental problems.

Figure 2 Evolution of the number of papers according to the subject matters (1980-2017) (see online version for colours)

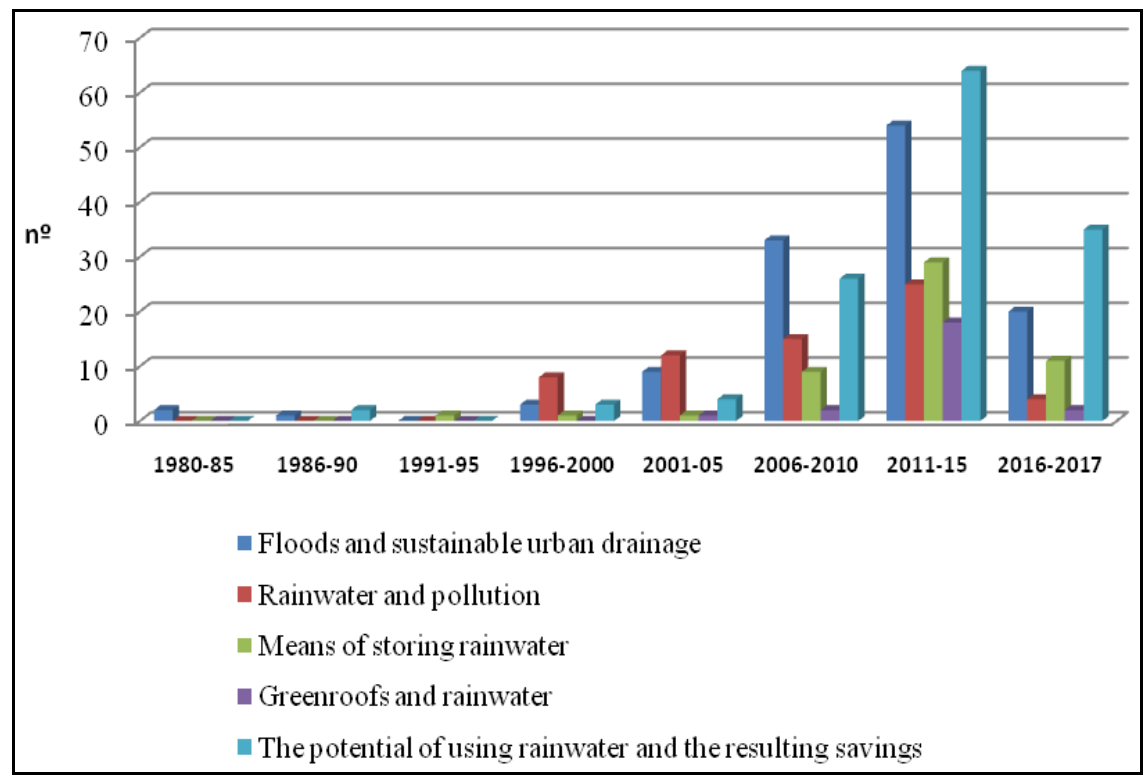

The analysis of the papers according to the study areas shows their concentration in three areas (Figure 3):

1 Europe with $57 \%$ of the studies (225 papers)

2 Australia with $24.61 \%$ of the studies (99)

3 the USA with $12.94 \%$ (51 studies).

To keep the explanation simple, the countries were grouped into these three large regional groups, which corresponded with the areas with the highest number of references. This does not mean that there is no reference to other countries (for example, Canada, Japan, New Zealand or Israel). All references are considered in each of the sections in which the research is structured and included in the rates where the territorial distribution is analysed (general level). But given the minority number of items (papers), it was not possible to collect them in the figures (their representation was not legible).

The main topics with reference to these three study areas show that:

1 In Europe, the main lines of research are concerned with 'floods and sustainable urban drainage' (78 papers, 34.7\%) and 'the potential of using rainwater and the resulting savings' (71 papers, $31.6 \%$ ).

2 In Australia, with 'floods and sustainable urban drainage' (32 studies, 32.9\%) and 'means of storing rainwater' (32 studies, 32.9\%). 
3 In the USA, studies about 'the potential of using rainwater and the resulting savings' (33 studies, 64.1\%).

Figure 3 Number of papers written per country and the main regions (the USA, Australia and Europe) (see online version for colours)

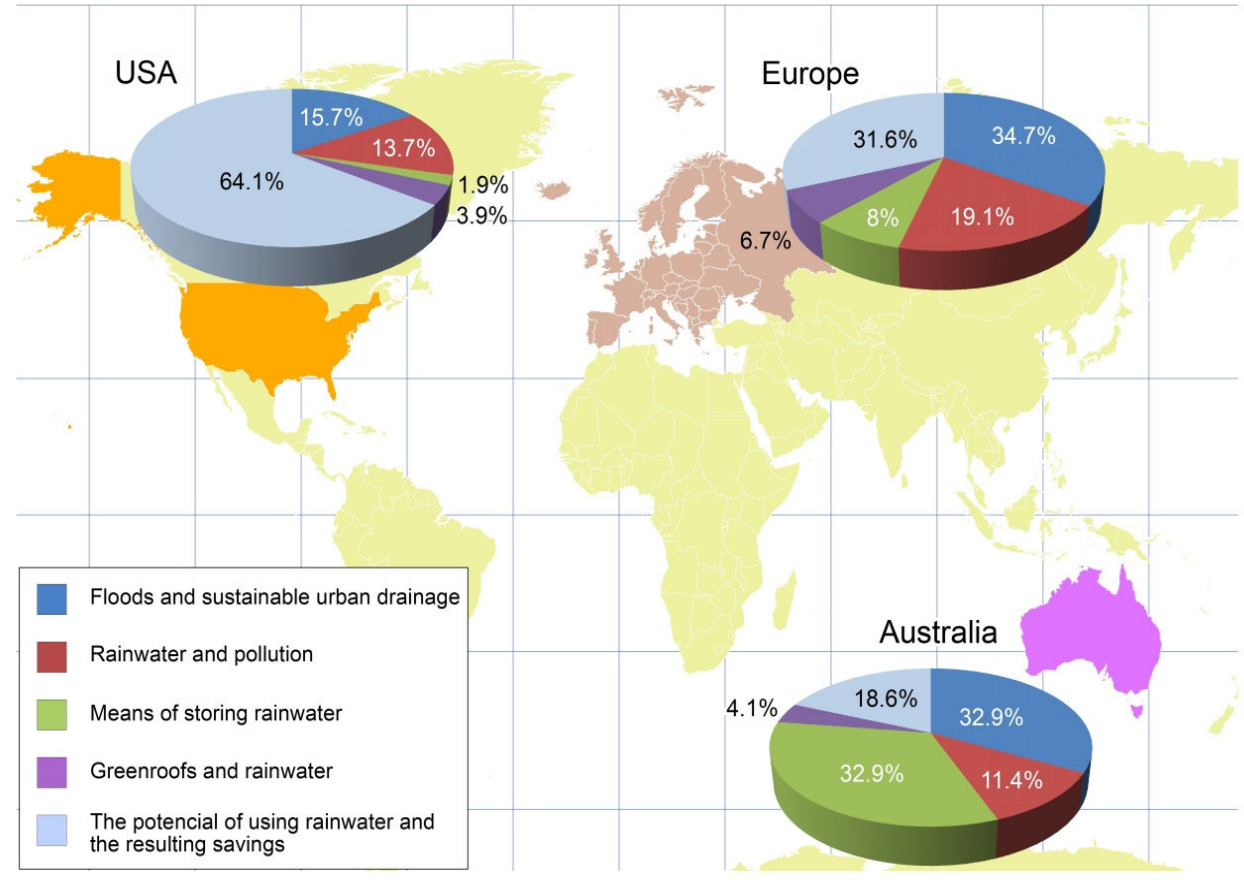

\subsection{Floods and sustainable urban drainage}

The studies related to floods and SUDS (a total of 122 papers) have been carried out over a long period of time, starting way back in the eighties when the first studies were published (Krejci and Gujer, 1985). And they peaked in the first decade of the 21 st century. From a geographical point of view, the publications from Europe are the majority (with 78 works) (Table 1). By regions, the studies are conducted in the North and Central Europe (mainly in the UK, Denmark, Germany, Austria, etc.), with a total of 59 papers and the Mediterranean Europe with 19 papers. With regard to the former group, for example, it is worth mentioning articles from the UK (Rubinato et al., 2013), Denmark (Zhou et al., 2013) or Germany (Staufer and Pinnekamp, 2008). Those from the Mediterranean Europe mainly come from Italy and Spain (ten and eight papers, respectively). The rest of the works are from outside Europe and, by countries, Australia with 32 papers is the main country, especially, in the current decade, and secondly, the USA (eight studies) (Table 1). 
Table 1 Number of papers published per main areas on floods and sustainable urban drainage

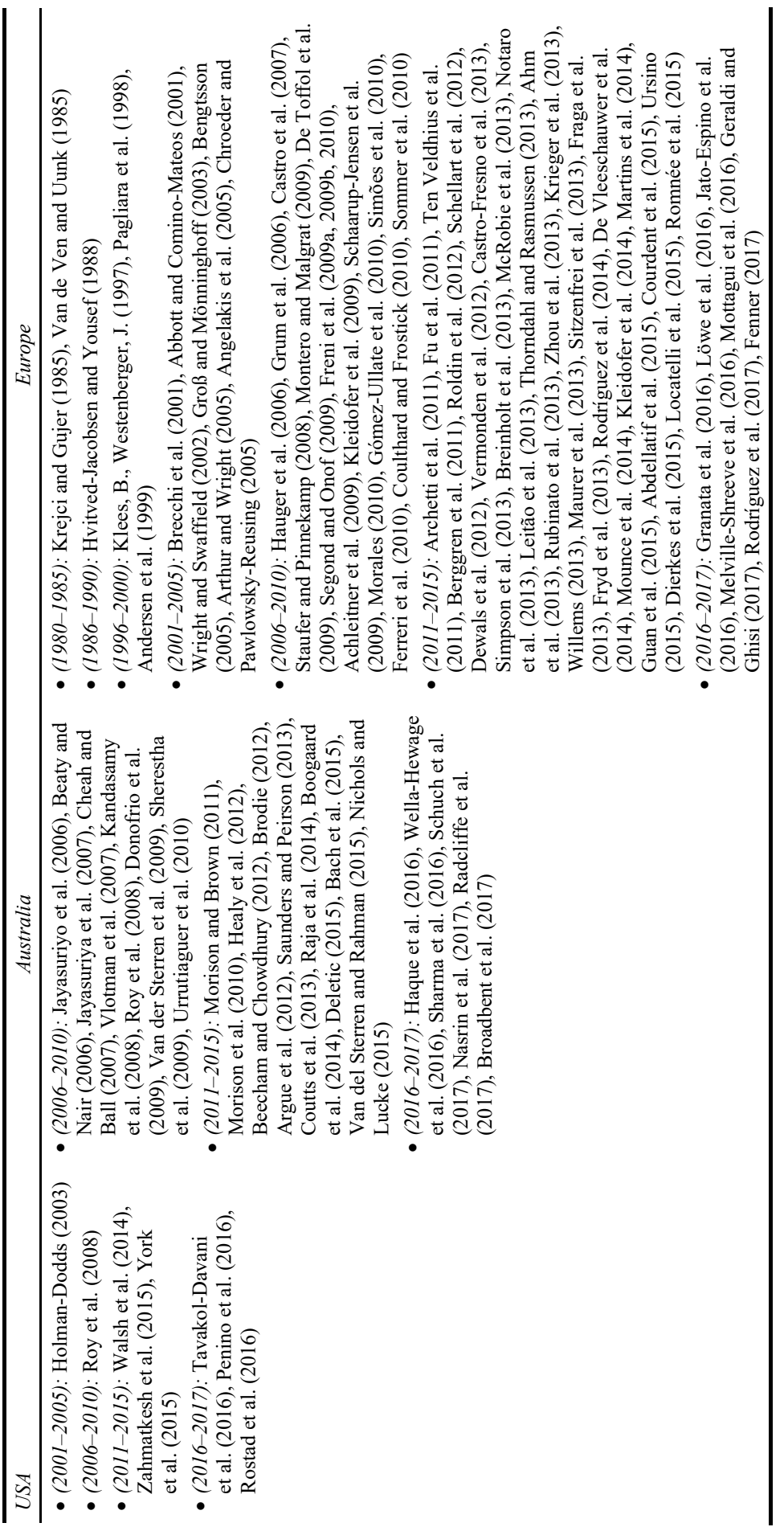


Elements that all these publications have in common are:

1 The description of the techniques used to calculate the volume of the circulating flow with the conventional drainage systems.

2 The circulating flow volumes when the SUDS are used and the mitigation of the damage done by floods.

3 The possible effects that climate change could have on the urban drainage and how it could be adapted (Courdent et al., 2015; Willems, 2013).

In this respect, flooding is the most common natural hazard in Europe and other developed countries. This explains the relevance of this section in this territorial area.

Table 2 Number of papers published per main areas on rainwater and pollution

\begin{tabular}{|c|c|c|}
\hline$U S A$ & Australia & Europe \\
\hline $\begin{array}{l}\text { - }(2001-2005) \text { : Dwight } \\
\text { et al. (2002), Bay et al. } \\
(2003), \text { Ahn et al. } \\
(2005) \\
\text { - }(2006-2010) \text { : Gilbert } \\
\text { and Clausen (2006), } \\
\text { Richardson and Tripp } \\
\text { (2006) } \\
\text { - }(2011-2015) \text { : De Busk } \\
\text { and Hunt (2014), } \\
\text { Wilson et al. (2014) }\end{array}$ & $\begin{array}{l}\text { - (2006-2010): Miguntanna } \\
\text { et al. (2010), Morrow et al. } \\
\text { (2010), Francey et al. } \\
\text { (2010), Bach et al. (2010) } \\
\text { - }(2011-2015) \text { : Wright et al. } \\
\text { (2011), Beecham et al. } \\
\text { (2012), Huston et al. } \\
\text { (2012), Daly et al. (2012), } \\
\text { Magyar et al. (2014), Raja } \\
\text { et al. (2014), Lucke and } \\
\text { Nichols (2015) }\end{array}$ & $\begin{array}{l}\text { - (1996-2000): Hermann (1996), } \\
\text { Krejci (1996), Deletic (1998), } \\
\text { Estèbe et al. (1998), Stieber et al. } \\
\text { (1999), Harremoës and Rauch } \\
\text { (1999), Zug et al. (1999), Vidal } \\
\text { and Melgar (2000) } \\
\text { - (2001-2005): Polkowska et al. } \\
\text { (2002), Mourad and Chebbo } \\
\text { (2005), Brombach et al. (2005), } \\
\text { Sage et al. (2005), Ahlman et al. } \\
\text { (2005), Gnecco et al. (2005), } \\
\text { Kafi-Benyahia et al. (2005) } \\
\text { - (2006-2010): Mourad et al. } \\
\text { (2006), Gnecco et al. (2006), } \\
\text { Ahlman (2006), Wallis et al. } \\
\text { (2006), Fach and Stubbe (2008), } \\
\text { Rossi (2008), Vermonden et al. } \\
\text { (2009), Mannina and Viviani } \\
\text { (2009), Schellart et al. (2010) } \\
\text { - (2011-2015): Birch et al. (2011), } \\
\text { Chèvre et al. (2011), Burkhardt } \\
\text { et al. (2011), Gromaire et al. } \\
\text { (2011), Vialle et al. (2012), Birch } \\
\text { et al. (2012), Métadier and } \\
\text { Bertrand-Krajewski (2012), } \\
\text { Gnecco et al. (2013), De Man } \\
\text { et al. (2014), Zawilski et al. } \\
\text { (2014), Bressy et al. (2014), } \\
\text { Todeschini et al. (2014), } \\
\text { Quinn and Dussaillant (2014), } \\
\text { Yan et al. (2014), Sales-Ortells } \\
\text { and Medema (2015), } \\
\text { Llopart-Mascaró et al. (2015) } \\
\text { - (2016-2017): Fraga et al. (2016), } \\
\text { Todeschini (2016), Komínková } \\
\text { et al. (2016) }\end{array}$ \\
\hline
\end{tabular}




\subsection{Rainwater and pollution}

In regard to the studies carried out on rainwater and pollution, 64 papers in total were analysed. As to the evolution over time, interest in this topic began halfway through the nineties with a more or less average number of publications being issued after this date (Deletic, 1998). This topic is mostly analysed in Europe (43 papers). Particularly, in Central and Northern European countries (36 papers), (France, Switzerland, the UK, Denmark, Holland, Germany, etc.) (Quinn and Dussaillant, 2014) more so than in the Mediterranean countries (7 papers) (Table 2). A special mention should be made to France that published 11 papers $(17 \%$ of the total). This distinct location is explained, to a great extent, by a longer track record in using SUDS and, consequently, a concern for the pollution of these flows and their possible use.

\subsection{Means of storing rainwater}

With regard to the studies carried out on the means of storing rainwater, a total number of 52 papers were identified. It is also important to note that the majority are related to issues that deal with the form and different types of infrastructure to store rainwater (for example, rainwater tanks) (Londra et al., 2015). Regarding the time analysis, interest in this topic begins at the beginning of the nineties (Lessard and Beck, 1991) with a growing number of publications, especially from the 2010 decade onwards (Table 3). From the point of view of its geographical distribution, the main region is Australia with 32 papers ( $61 \%$ of the total of this research line), and in second place Europe with 18 studies (34\%). It is important to note that this topic is popular in areas characterised by scarcity of water like some areas of Australia (Imteaz et al., 2017) and in the Mediterranean countries such Spain (Andrés-Doménech et al., 2012), Greece (Yannopoulos et al., 2017) and Italy (Campisano and Modica, 2016).

\subsection{Greenroofs and rainwater}

In regard with the thematic of 'greenroofs and rainwater', it should be noted that:

1 The adoption of these systems does not have the main purpose of harvesting and/or reusing rainwater.

2 Indicate the possibilities that can be offered to achieve more sustainable urban spaces with the use rainwater resources (storage for domestic uses and for watering gardens, etc.).

In total, a number of 22 papers have been identified, especially in the last decade. By region, Europe stands out (18 research articles, $81 \%$ ), with the majority concentrating in the UK with nine papers (Graceson et al., 2014; Nawaz et al., 2015) (Table 4). In this country, the analysis of the 'greenroofs' is related to the abundance of rainfall. And therefore, it is a vital resource to be taken advantage of to replace certain consumptive water uses. 
Table 3 Number of papers published per main areas on means of storing rainwater

\begin{tabular}{|c|c|c|}
\hline$U S A$ & Australia & Europe \\
\hline 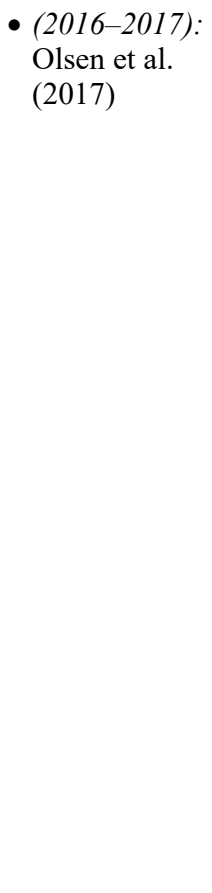 & $\begin{array}{l}\text { - (2001-2005): Coombes and } \\
\text { Kuczera (2003) } \\
\text { - (2006-2010): Collins (2008), } \\
\text { Sharma et al. (2008), Gardiner } \\
\text { (2009), Khastagir and Jayasuriya } \\
\text { (2010), Rodrigo et al. (2010), } \\
\text { Eroksuz and Rahman (2010), Tam } \\
\text { et al. (2010), Andrés-Doménech } \\
\text { et al. (2010), Khastagir et al. (2010) } \\
\text { - (2011-2015): Imteaz et al. (2011a, } \\
\text { 2011b, 2012, 2013, 2014), } \\
\text { Gato-Trinidad and Gan (2011), } \\
\text { Van der Sterren et al. (2012, 2013, } \\
\text { 2014), Rahman et al. (2012), } \\
\text { Mankad et al. (2012), Beal et al. } \\
\text { (2012), Umaphati et al. (2013), } \\
\text { Cook et al. (2013), Moglia and } \\
\text { Tjandraatmadja (2014), } \\
\text { Gato-Trinidad and Gan (2014), } \\
\text { Demuzere et al. (2014), Delaney and } \\
\text { Fam (2015) } \\
\text { - (2016-2017): Imteaz et al. (2016, } \\
\text { 2017a, 2017b), Kandasamy et al. } \\
\text { (2016), Sountharajah et al. (2017) }\end{array}$ & $\begin{array}{l}\text { - (1991-1995): Lessar and Beck } \\
\text { (1991) } \\
\text { - (1996-2000): Van Wesemael } \\
\text { et al. (1998) } \\
\text { - }(2011-2015) \text { : López-Patiño } \\
\text { et al. (2011), Campisano and } \\
\text { Modica (2012), Todeschini et al. } \\
\text { (2012), Andrés-Doménech et al. } \\
\text { (2012), Garcia et al. (2013), } \\
\text { Tsihrintzis and Baltas (2014), } \\
\text { Ringelstein (2015), Londra et al. } \\
\text { (2015), Gerolin and Le Nouveau } \\
\text { (2015) } \\
\text { - (2016-2017): Campisano and } \\
\text { Modica (2016), Angelakis } \\
\text { (2016), Enriquez et al. (2017), } \\
\text { Yannopoulos et al. (2017) }\end{array}$ \\
\hline
\end{tabular}

Table 4 Number of papers published per main areas on greenroofs and rainwater

\begin{tabular}{|c|c|c|}
\hline$U S A$ & Australia & Europe \\
\hline $\begin{array}{l}\text { - }(2006-2010): \\
\text { Deutsh (2007) } \\
\text { - }(2011-2015): \\
\text { Gregoire and } \\
\text { Clausen (2011) }\end{array}$ & $\begin{array}{l}\text { - }(2011-2015) \text { : Razzaghmanesh } \\
\text { et al. (2014), Razzaghmanesh } \\
\text { and Beecham (2014), Beecham } \\
\text { and Razzaghmanesh (2015) } \\
\text { - (2016-2017): Razzaghmanesh } \\
\text { et al. (2016) }\end{array}$ & $\begin{array}{l}\text { - }(2001-2005) \text { : Bengtsson et al. } \\
\text { - }(2005) \\
\text { - }(2011-2015): \text { Stovin et al. (2012), } \\
\text { Gnecco et al. (2013), Yio et al. } \\
\text { (2013), Speak et al. (2013), } \\
\text { Vesuviano and Stovin (2013), } \\
\text { Graceson et al. (2013), Vanuytrecht } \\
\text { et al. (2014), Carbone et al. (2014), } \\
\text { Vesuviano et al. (2014), Locatelli } \\
\text { et al. (2014), Graceson et al. (2014), } \\
\text { Stratigea and Makropoulos (2015), } \\
\text { Nawaz et al. (2015) } \\
\text { - (2016-2017): Johannessen et al. } \\
\text { (2017) }\end{array}$ \\
\hline
\end{tabular}


Table 5 Number of papers published per main areas on the potential of using rainwater and the resulting savings

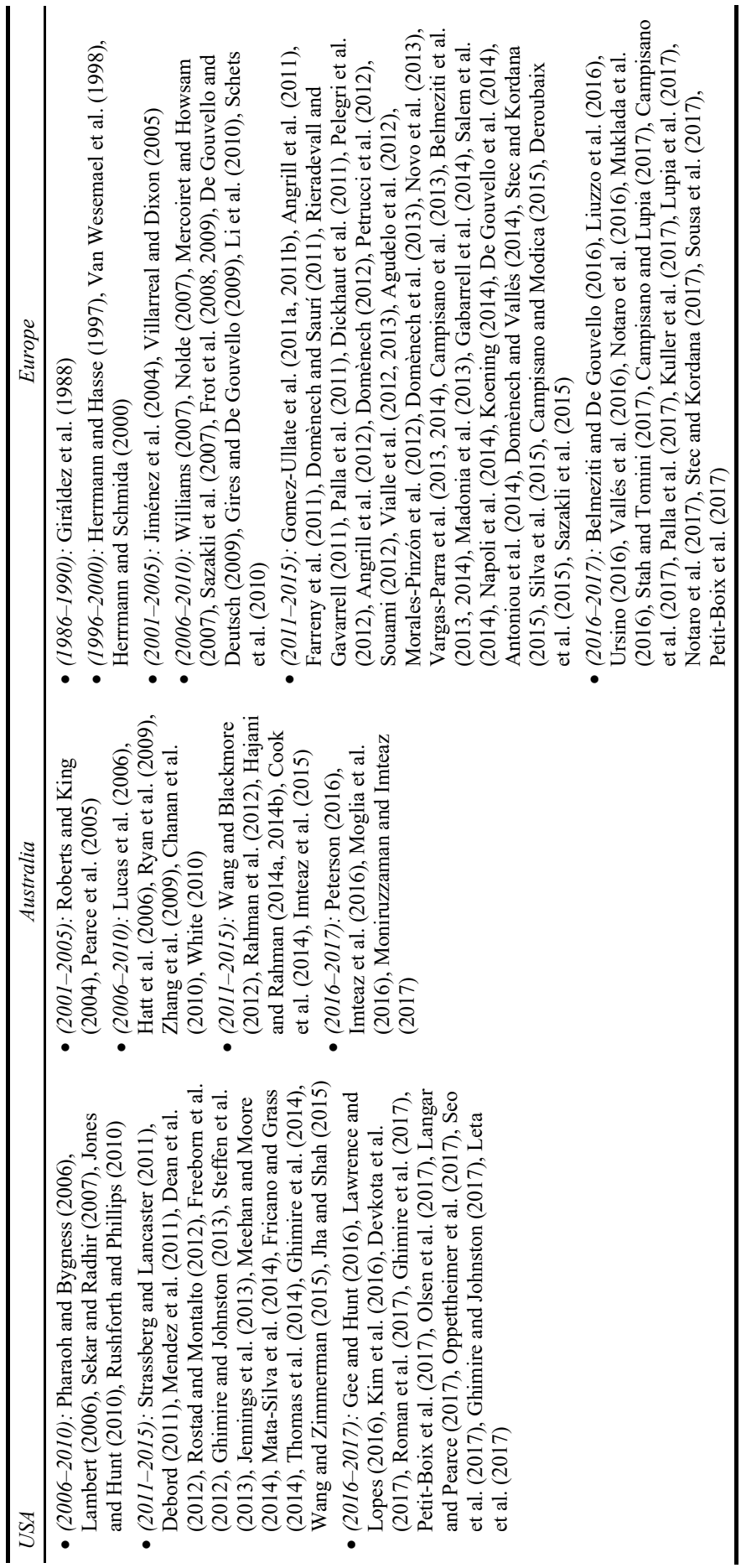




\subsection{The potential of using rainwater and the resulting savings}

One hundred thirty-four publications in total are associated with the potential of using rainwater and the resulting water savings. In terms of its interest over the years, it begins gradually in the ' 80 s and '90s (Giráldez et al., 1988). But it is not until halfway through the first decade of the 21 st century and especially from 2010 onwards that it becomes widely studied. From the point of view of its spatial location, the highest percentage of papers is concentrated in Europe (71 papers, the 52.98\%). Particularly in countries from the Mediterranean Europe, for example Spain (25 papers, the 18.65\%), France (12 papers, the $8.9 \%$ ) and Italy (11 papers, 8.20\%) (Table 5). In general, it is in these countries where the subtopic related to how much drinking water is saved if rainwater is used instead, especially at home, is highlighted. This is all related to the shortage of resources in certain regions in the aforesaid countries. And especially, due to the growing demand for water used for urban-tourist purposes on the coastline. Outside Europe, the total number of papers is 63: the USA with 33 studies (24.62\%) and Australia with 18 studies $(13.43 \%)$.

\section{Discussion}

This research has shown how studies related to the use and potential of rainwater in urban areas of the developed world began to be treated in the eighties of the last century. Nevertheless, they have acquired greater relevance in recent years, mainly due to five factors that have been identified as 'subjects of study' related to RWH: floods and sustainable urban drainage; rainwater and pollution; means of storing rainwater; greenroofs and rainwater; and the potential of using rainwater and the resulting savings.

In the topic 'floods and sustainable urban drainage', the most important are publications that relate new drainage systems and the mitigation of flood risk. In recent years, the interest in this subject has been accentuated due to the effects of climate change such as greater intensity of rainfall. By geographical areas, Europe (the UK, Denmark, Italy, Spain and Germany) and the USA dominate. The use and management of decentralised and alternative water resources, such as rainwater, can help to take the pressure off conventional water resources and add a series of benefits form the point of view of the urban policies and water management. It could be an important step towards a more democratic society were environmental resources are controlled by the citizenry and are used in a rational and recyclable manner (Domènech et al., 2013). According to Belmeziti et al. (2013), the practice of RWH is catching on quickly in urban areas. This statement is highlighted in this research. This is due to the different benefits to be had when rainwater is used. Firstly, using rainwater means that the urban streets are drained properly and floods can therefore be avoided in certain urban areas. Williams (2007), for example, explains that RWH slows down its flow into the watercourses, which is exacerbated by the growth in the urban development and the reduction in vegetation cover. Moreover, RWH, which can be used as a supplementary solution to pumping, could also reduce the amount of water wasted in flash flooding to avoid drought in dry and wet seasons.

The second research line identified is 'rainwater and pollution'. By countries and research papers identified, France (Mourad and Chebbo, 2005), the USA (Wilson et al., 2014) and Australia (Lucke and Nichols, 2015) stand out. These publications discuss the 
measures taken in different countries or the methods used to find out more about the best practices and the pollution levels in the first flush. In France, Sage et al. (2015) carried out through a literature analysis to determine how suitable they are to control pollution and what influence they have on the selection and design of best management practices. This study suggests that hydrologic criteria based on volume reduction (rather than treatment) might generally be preferable for the onsite control of diffuse stormwater pollution. In the Mediterranean area (Italy), Gnecco et al. (2005), from two monitoring systems (roof and road runoff) installed in the experimental catchment of Villa Cambiaso (University of Genoa) investigate the first flush phenomenon connected to different types of urban surfaces. It was observed that the pollution by heavy metals in first flush is affected by both the rainfall characteristics (intensity and total depth) and the preceding environmental conditions

In the research line 'means of storing rainwater' papers related to the storage of rainwater through 'rainwater tanks' stand out. In these papers, most studies focused on the key role played by climate conditions to size storm tanks (Andrés-Doménech et al., 2010) or to evaluate the potential of tank-based RWH systems in houses to mitigate peak roof runoff due to rainfall in urban areas (Campisano and Modica, 2016). Countries such as Australia, Spain or Italy stand out by number of publications. The prevalence of semiarid weather conditions in some regions of these countries with water shortage justifies its relevance. In addition, in Spain and Italy, it is also necessary to mention the existence of traditional rainwater storage techniques (cisterns).

These traditional uses, neglected since the second half of the S. XX (see Morote and Hernández, 2017) have 'emerged' in some urban areas (urbanisations, public buildings, etc.), as a way to store and harvest runoff water for further treatment and use. Although the majority of articles have been published in the Mediterranean area, this topic has also been under analysis in publications in Central and Northern Europe. For example, it is worth mentioning the article published in Belgium by Ringelstein (2015). In this country, RWH tanks is mandatory for new buildings in most regions. In this study, the author argues that the greatest water savings are obtained by using rainwater in flush toilets and showers in front of its use to watering gardens.

Fourth, papers related to 'greenroofs' analysed:

1 The relationships between weather conditions and the type of dwelling (detached house) that have allowed these systems to be implemented in the last decades to take advantage of rainwater for certain domestic uses.

2 The water storage capacities of the vegetation used on greenroofs. According to Speak et al. (2013), intensive greenroofs, with their deeper substrates and higher plant biomass, are able to retain greater quantities of runoff. Yio et al. (2013) concur on this point. They quantify the detention effects due to greenroof substrates and argue that greenroofs could contribute significantly to urban stormwater management. In the same country (the UK), Graceson et al. (2013) examine the contribution of growing media composition and depth to the water retention capabilities of greenroof systems.

3 The relationship between greenroofs and their capacity for reducing peak flow and flooding in urban areas (Graceson et al., 2014) by reducing the amount impermeable surfaces on built land (Arthur and Wright, 2005; Graceson et al., 2013). 
4 In urban environment, the use of greenroofs might be a sustainable solution to abate the quantity and quality of urban runoff. They enable to retain a portion of drained rainwater and to reduce a heated island effect due to the configuration of green areas (Carbone et al., 2014). However, according to Nawaz et al. (2015), empirical evidence from full-scale roofs, especially those that have been operational for more than several years, is limited. It is pointed out that there is a need for more studies on this less common type of greenroof. It is also indicated that it would be convenient to investigate the effect of factors such as age and vegetation composition (Speak et al., 2013).

Despite the geographical concentration of this topic in the UK, studies have also been carried out in other countries in Central and Northern Europe and to a lesser extent in the Mediterranean countries. In Denmark, Locatelli et al. (2014) demonstrate the capacity of storage of this type of roofs. A few millimetres of storage can reduce the mean annual runoff by up to $20 \%$ compared to a traditional roof. In Italy, Carbone et al. (2014) show the hydraulic response of a greenroof in the Mediterranean climate during dry and wet weather conditions. In Greece, Stratigea and Makropoulos (2015) focus on the role of greenroofs, RWH and greywater reuse and their integration in buildings. The results suggest that the most preferable solution to store drinking water is RWH together with greywater recycling. And to minimise runoff, the best option is the greenroof combined with greywater recycling.

Finally, the topic 'potential of using rainwater and the resulting savings' contains the greatest number of articles, especially in countries such as the USA, Australia, Spain and Italy. The shortage of water resources due to climatic factors and increased demands makes this technique a system that can increase the available resources. RWH could increase the resilience of these territories, especially taking into account the effects of climate change (Figure 4). In the Mediterranean area, water scarcity is due to the increasing water demand related to the population growth and the expansion of urban and industrialised areas. RWH may be an effective alternative water supply solution to deal with water scarcity in order to reduce drinking and non-drinking water needs. It has recently become a particularly important option in arid and semi-arid areas, mostly because of its many benefits and relatively low costs (Notaro et al., 2017).

The integration of RWH systems with other water sources can result in significant water savings particularly for non-drinking household uses (Liuzzo et al., 2016; Morote and Hernández, 2017). In Italy, Liuzzo et al. (2016) analyse the reliability of using this system to supply water to flush the toilet and for the garden irrigation, for a detached house in a residential area of Sicily (Southern Italy). A cost-benefit analysis is that there are environmental and economic advantages in using a RWH system in Sicily compared to the traditional water supply methods. In addition, the regional analysis identified areas where the use of this system would be most effective. According to López-Zavala et al. (2016), using RWH together with greywater treatment and reuse would contribute to decrease drinking water consumption and the need to treat wastewater. Furthermore, it would also help attain significant economic savings for water users and water or wastewater system operators. This shows that incorporating RWH and greywater reuse is more feasible and reliable than strategies based on only RWH.

A second question analysed is the effectiveness of this technique in relation to weather conditions. In Italy, Ursino (2016) studied the efficiency of a large number of urban water reuse systems, operating under different climate and demand conditions. In 
the study by De Gouvello et al. (2014), based on a detailed analysis of eight countries (Germany, the UK, the US, Brazil, India, Sri Lanka, Australia and Uganda), an international overview of RWH is compiled. Apart from the specific and sensitive differences, the experience of these countries is useful for the French case. Comparisons have been made on different aspects: uses of rainwater, quality standards, regulatory tools and RWH development factors.

Figure 4 Example of RWH system (see online version for colours)

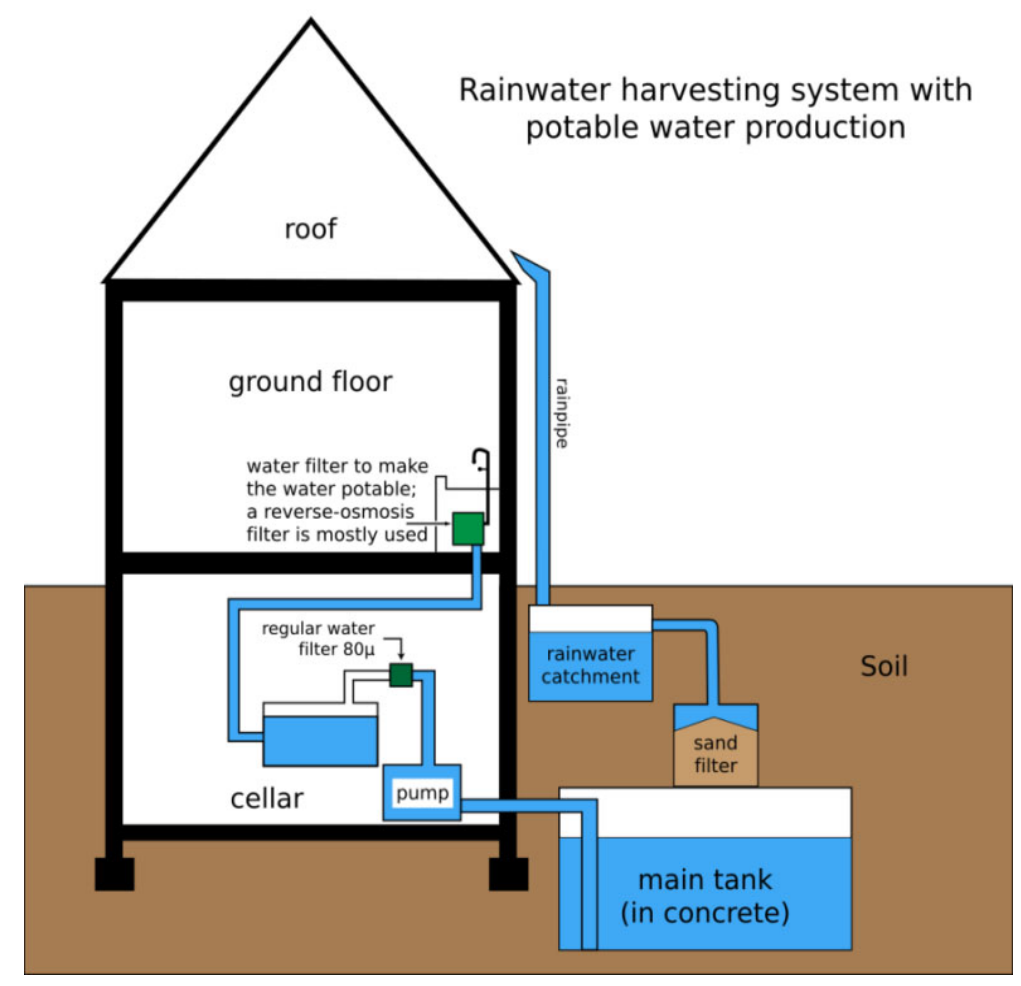

Source: http://pt.m.wikiversity.org

Despite acquiring increasingly more experience, planners frequently disregard RWH for domestic consumption for two main reasons. First, not enough is known about the benefits of RWH for its users. Most studies have focused on theoretically estimating the water collection potential of RWH (Eroksuz and Rahman, 2010). A lower number base their arguments on fact according to the current performance and use of existing RWH systems. A smaller number do explore users' practices and perceptions (for some exceptions, see Baguma et al., 2010; Thomas et al., 2014). Although in both cases, the number of researches has increased in recent years. The cost of RWH systems is usually perceived as being high, but the economic analysis usually fails to consider life cycle costs and various positive externalities (Batchelor et al., 2011). In this sense, Domènech et al. (2013) argue that governments may be reluctant to promote this technology because of the uncertainty about the users' ability to manage the system appropriately and the associated health risks. 


\section{Conclusions}

The use and the management of rainwater in urban areas of the developed world (and also in developing countries) could play a central role in increasing water security and reducing the negative impact on the environment (El-Sayed et al., 2010). Indeed, RWH may turn hazards (floods and polluted water) into local resources (water for certain uses). Nowadays, domestic RWH practices are recognised as being effective tools to improve the sustainability of drainage systems within the urban environment. They help limit the demand for drinking water (replace certain consumptive water uses), and at the same time, they can mitigate the generation of stormwater runoff at the source (Campisano et al., 2013).

Furthermore, the future climate change scenarios, forecast that in some regions (for example the Mediterranean area), water resources will become scarcer due to drought episodes becoming more frequent and intense, whilst rainfall will be more intense and concentrated in time (IPCC, 2018). All these arguments mean that many countries, as demonstrated in this bibliometric analysis, are interested in adopting these practices. In relation with the principles of 'IWRM' and 'the demand management approach', RWH, which was once considered to be a hazard, is now thought of as a water resource, which can help take the pressure off the conventional water resources.

Rainwater may be an effective alternative water solution in regions affected by water scarcity as shown by the large number of articles that have been written on this subject matter. Its many benefits and affordable costs (Liuzzo et al., 2016) or its use in both indoor (for example, in toilets) and outdoor (watering the garden) uses that require lower quality water are recurring themes. The Spanish examples of San Cugat del Vallés (Vallès-Casas et al., 2016) or the city of Alicante (Morote and Hernández, 2017) are representative. This is the example of the European Mediterranean. One of the areas that is most at risk of water shortage, mainly due to the growth of the urban population and the development of different economic activities, such as tourism and irrigated areas, which is made even worse with the effects of global climate change. Finally, it is important to assess the importance of unconventional water in responding to when the consequences of the climate change one of the biggest challenges to societies on a global scale (IPCC, 2014, 2018).

\section{References}

Alamdari, N., Sample, D.J., Liu, J. and Ross, A. (2018) 'Assessing climate change impacts on the reliability of rainwater harvesting systems', Resources, Conservation and Recycling, Vol. 132, No. 132, pp.178-189, https://doi.org/10.1016/j.resconrec.2017.12.013.

Andrés-Doménech, I., Montanari, A. and Marco, J.B. (2010) 'Stochastic rainfall analysis for storm tank performance evaluation', Hydrology and Earth System Sciences, Vol. 14, No. 7, pp.1221-1232.

Andrés-Doménech, I., Montanari, A. and Marco, J.B. (2012) 'Efficiency of storm detention tanks for urban drainage systems under climate variability', Journal of Water Resources Planning and Management, Vol. 138, No. 1, pp.36-46.

Arthur, S. and Wright, G.B. (2005) 'Recent and future advances in roof drainage design and performance', Building Services Engineering Research and Technology, Vol. 26, No. 4, pp.337-348. 
Baguma, D., Loiskandl, W., Darnhofer, I., Jung, H. and Hauser, M. (2010) 'Knowledge of measures to safeguard harvested rainwater quality in rural domestic households', J. Water Health, Vol. 8, No. 2, pp.334-345.

Bashar, M.Z.I., Karim, M.R. and Imteaz, M.A. (2018) 'Reliability and economic analysis of urban rainwater harvesting: a comparative study within six major cities of Bangladesh', Resources, Conservation and Recycling, Vol. 133, No. 133, pp.146-154, https://doi.org/10.1016/ j.resconrec.2018.01.025.

Batchelor, C., Fonseca, C. and Smits, S. (2011) Life-cycle Costs of Rainwater Harvesting Systems, Occasional Paper No. 46, IRC International Water and Sanitation Centre, WASHCost and RAIN, The Hague, The Netherlands.

Belmeziti, A., Coutard, O. and De Gouvello, B. (2013) 'A new methodology for evaluating potential for potable water savings (PPWS) by using rainwater harvesting at the urban level: the case of the municipality of Colombes (Paris region)', Water, Vol. 5, No. 1, pp.312-326.

Brown, R., Farrelly, M. and Keath, N. (2009) 'Practitioner perceptions of social and institutional barriers to advancing a diverse water source approach in Australia', Water Resources Development, Vol. 25, No. 1, pp.15-28.

Campisano, A. and Modica, C. (2016) 'Rainwater harvesting as source control option to reduce roof runoff peaks to downstream drainage systems', Journal of Hydroinformatics, Vol. 18, No. 1, pp.23-32, DOI: 10.2166/hydro.2015.133.

Campisano, A., Gnecco, I., Modica, C. and Palla, A. (2013) 'Designing domestic rainwater harvesting systems under different climatic regimes in Italy', Water Science and Technology, Vol. 67, No. 11, pp.2511-2518.

Carbone, M., Nigro, G., Garofalo, G. and Piro, P. (2014) 'The hydrological performance of a green roof: an experimental study in the university of Calabria, Italy', WIT Transactions on Ecology and the Environment, Vol. 191, No. 2, pp.1661-1669.

Courdent, V., Vezzaro, L., Mikkelsen, P.S., Mollerup, A.L. and Grum, M. (2015) 'Using ensemble weather forecast in a risk based real time optimization of urban drainage systems', La Houille Blanche, Vol. 2, pp.101-107, DOI: 10.1051/1hb/20150025.

De Gouvello, B., Gerolin, A. and Le Nouveau, N. (2014) 'Rainwater harvesting in urban areas: how can foreign experiences enhance the French approach?', Water Science and Technology: Water Supply, Vol. 14, No. 4, pp.569-576.

Domènech, L., March, H. and Saurí, D. (2013) 'Degrowth initiatives in the urban water sector? A social multi-criteria evaluation of non-conventional water alternatives in Metropolitan Barcelona', Journal of Cleaner Production, Vol. 38, No. 38, pp.44-55, https://doi.org/10. 1016/j.jclepro.2011.09.020.

Donofrio, J., Kuhn, Y., McWalter, K. and Winsor, M. (2009) 'Research article: water-sensitive urban design: an emerging model in sustainable design and comprehensive water-cycle management', Environmental Practice, Vol. 11, No. 3, pp.179-189, DOI: 10.1017/ S1466046609990263.

El-Sayed, M., Mahgoub, M., Van der Steen, N.P., Abu-Zeid, K. and Vairavamoorthy, K. (2010) 'Towards sustainability in urban water: a life cycle analysis of the urban water system of Alexandria City, Egypt', J. Clean Prod., Vol. 18, Nos. 10-11, pp.1100-1106.

Ennenbach, M.W., Concha Larrauri, P. and Lall, U. (2018) 'County-scale rainwater harvesting feasibility in the United States: climate, collection area, density, and reuse considerations', Journal of the American Water Resources Association, Vol. 54, No. 1, pp.255-274.

Eroksuz, E. and Rahman, A. (2010) 'Rainwater tanks in multi-unit buildings: a case study for three Australian cities', Resour. Conserv. Recy., Vol. 54, No. 12, pp.1449-1452.

Fisher-Jeffes, L.N., Armitage, N.P. and Carden, K. (2017) 'The viability of domestic rainwater harvesting in the residential areas of the Liesbeek River catchment, Cape Town', Water SA, Vol. 43, No. 1, pp.81-90, DOI: 10.4314/wsa.v43i1.11. 
Giráldez, J.V., Ayuso, J.L., Garcia, A., López, J.G. and Roldán, J. (1988) 'Water harvesting strategies in the semiarid climate of southeastern Spain', Agricultural Water Management, Vol. 14, Nos. 1-4, pp.253-263.

Gnecco, I., Berretta, C., Lanza, L.G. and La Barbera, P. (2005) 'Storm water pollution in the urban environment of Genoa, Italy', Atmospheric Research, Vol. 77, Nos. 1-4, pp.60-73.

Graceson, A., Hare, M., Monaghan, J. and Hall, N. (2013) 'The water retention capabilities of growing media for green roofs', Ecological Engineering, Vol. 61, No. PA, pp.328-334.

Graceson, A., Monaghan, J., Hall, N. and Hare, M. (2014) 'Plant growth responses to different growing media for green roofs', Ecological Engineering, Vol. 69, pp.196-200, DOI: 10.1016/ j.ecoleng.2014.03.067.

Grant, A.T.J., McKinney, N.L. and Ries, R. (2018) 'An approach to quantifying rainwater harvesting potential using imagery, geographic information systems (GIS) and LiDAR data', Water Science and Technology: Water Supply, Vol. 18, No. 1, pp.108-118.

Imteaz, M.A. and Moniruzzaman, M. (2018) 'Spatial variability of reasonable government rebates for rainwater tank installations: a case study for Sydney', Resources, Conservation and Recycling, Vol. 133, No. 133, pp.112-119, https://doi.org/10.1016/j.resconrec.2018.02.010.

Imteaz, M.A., Karki, R., Shamseldin, A. and Matos, C. (2017) 'eTank and contemporary online tools for rainwater tank outcomes analysis', International Journal of Computer Aided Engineering and Technology, Vol. 9, No. 3, DOI: 10.1504/IJCAET.2017.084904.

Intergovernmental Panel on Climate Change (IPCC) (2014) Climate Change 2013 and Climate Change 2014, 3 vols. [online] http://www.ipcc.ch/ (accessed 25 September 2017).

Intergovernmental Panel on Climate Change (IPCC) (2018) Special Report Global Warming of $1.5^{\circ} \mathrm{C}$ [online] https://www.ipcc.ch/report/sr15/ (accessed 11 September).

Jayasuriya, L.N.N., Kadurupokune, N., Othman, M. and Jesse, K. (2007) 'Contributing to the sustainable use of stormwater: the role of pervious pavements', Water Science and Technology, Vol. 56, No. 12, pp.69-75, DOI: 10.2166/wst.2007.753.

Jing, X., Zhang, S., Zhang, J., Wang, Y. and Wang, Y. (2017) 'Assessing efficiency and economic viability of rainwater harvesting systems for meeting non-potable water demands in four climatic zones of China', Resources, Conservation and Recycling, Vol. 126, pp.74-85, DOI: $10.1016 /$ j.resconrec.2017.07.027.

Kandasamy, J., Kus, B. and Vigneswaran, S. (2016) 'Rainwater harvesting in New South Wales, Australia', Green Technologies for Sustainable Water Management, pp.35-74, DOI: 10.1061/ 9780784414422.ch02.

Krejci, V. and Gujer, W. (1985) 'Area wide strategies for storm water management in Switzerland: case study Glattal', U.S. EPA Water Quality Models Meeting, University of Florida, Ganesville, EE.UU.

Lessard, P. and Beck, M.B. (1991) 'Dynamic simulation of storm tanks', Water Research, Vol. 25, No. 4, pp.375-391.

Li, Y-H., Tung, C.P. and Chen, P.Y. (2017) 'Stormwater management toward water supply at the community scale - a case study in northern Taiwan', Sustainability, Vol. 9, No. 7, Art. no. 1206, DOI: 10.3390/su9071206.

Liuzzo, L., Notaro, V. and Freni, G. (2016) 'A reliability analysis of a rainfall harvesting system in southern Italy', Water, Vol. 8, p.18, DOI: 10.3390/w8010018.

Locatelli, L., Mark, O., Mikkelsen, P.S., Arnbjerg-Nielsen, K., Bergen Jensen, M. and Binning, P.J. (2014) 'Modelling of green roof hydrological performance for urban drainage applications', Journal of Hydrology, 27 November, Vol. 519, Part D, pp.3237-3248, https://doi.org/10.1016/ j.jhydrol.2014.10.030.

Londra, P.A., Theocharis, A.T., Baltas, E. and Tsihrintzis, V.A. (2015) 'Optimal sizing of rainwater harvesting tanks for domestic use in Greece', Water Resources Management, Vol. 29, No. 12, pp.4357-4377. 
Lopes, V.A.R., Marques, G.F., Dornelles, F. and Medellin-Azuara, J. (2017) 'Performance of rainwater harvesting systems under scenarios of non-potable water demand and roof area typologies using a stochastic approach', Journal of Cleaner Production, Vol. 148, pp.304-313, DOI: 10.1016/j.jclepro.2017.01.132.

López-Zavala, M.A., Castillo Vega, R. and López Miranda, R.A. (2016) 'Potential of rainwater harvesting and greywater reuse for water consumption reduction and wastewater minimization', Water, Vol. 8, No. 6, p.264, https://doi.org/10.3390/w8060264.

Lucke, T. and Nichols, P.W.B. (2015) 'The pollution removal and stormwater reduction performance of street-side bioretention basins after ten years in operation', Science of the Total Environment, Vol. 536, No. 536, pp.784-792.

Morison, P.J. and Brown, R.R. (2011) 'Understanding the nature of publics and local policy commitment to water sensitive urban design', Landscape and Urban Planning, Vol. 99, No. 2, pp.83-92, DOI: 10.1016/j.landurbplan.2010.08.019.

Morote, A.F. and Hernández, M.H. (2017) 'El uso de aguas pluviales en la ciudad de Alicante. De Viejas ideas a nuevos enfoques', Papeles de Geografia, Vol. 63, pp.7-25, DOI: http://dx.doi.org/10.6018/geografia/2017/267531.

Mourad, M. and Chebbo, G. (2005) 'Sensitivity to experimental data of pollutant site mean concentration in stormwater runoff', Water Science \& Technology, Vol. 51, No. 2, pp.155-162.

Musayev, S., Burgess, E. and Mellor, J. (2018) 'A global performance assessment of rainwater harvesting under climate change', Resources, Conservation and Recycling, Vol. 132, No. 132, pp.62-70, https://doi.org/10.1016/j.resconrec.2018.01.023.

Nawaz, R., McDonald, A. and Postoyko, S. (2015) 'Hydrological performance of a full-scale extensive green roof located in a temperate climate', Ecological Engineering, Vol. 82, No. 82, pp.66-80, https://doi.org/10.1016/j.ecoleng.2014.11.061.

Notaro, V., Liuzzo, L. and Freni, G. (2017) 'Evaluation of the optimal size of a rainwater harvesting system in Sicily', Journal of Hydroinformatics, Vol. 19, No. 6, pp.853-864, DOI: $10.2166 /$ hydro.2017.150.

Okhravi, S., Eslamian, S. and Adamowski, J. (2015) 'Water reuse in rainwater harvesting', in Eslamian, S. (Ed.): Urban Water Reuse Handbook, Ch. 59, pp.779-796, Taylor and Francis, CRC Group [online] https://www.crcpress.com/Urban-Water-Reuse-Handbook/Eslamian/p/ book/9781482229141.

Okhravi, S., Eslamian, S., Eslamian, F. and Tarkesh-Esfahani, S. (2014) 'Indigenous knowledge as a supportive tool for sustainable development and utilisation of rainwater harvesting systems', Journal of Flood Engineering, Vol. 5, Nos. 1/2, pp.39-50.

Paudel, U., Imteaz, M.A. and Matos, C. (2018) 'Equations for potential water savings through rainwater harvesting for different climatic conditions in Adelaide (Australia)', International Journal of Hydrology Science and Technology, Vol. 8, No. 1, pp.91-104, DOI: 10.1504/ IJHST.2018.088678.

Petit-Boix, A., Devkota, J., Phillips, R., Vargas-Parra, M.V., Josa, A., Gabarrell, X., Rieradevall, J. and Apul, D. (2018) 'Life cycle and hydrologic modeling of rainwater harvesting in urban neighborhoods: implications of urban form and water demand patterns in the US and Spain', Science of the Total Environment, Vol. 621, pp.434-443, DOI: 10.1016/j.scitotenv.2017.11. 206.

Quinn, R. and Dussaillant, A. (2014) 'Predicting infiltration pollutant retention in bioretention sustainable drainage systems: model development and validation', Hydrology Research, Vol. 45, No. 6, pp.855-867.

Rahman, A., Hajani, E. and Eslamian, S. (2017) 'Rainwater harvesting in arid regions of Australia', in Eslamian, S. and Eslamian, F. (Eds.): Handbook of Drought and Water Scarcity: Environmental Impacts and Analysis of Drought and Water Scarcity, Vol. 2, Ch. 26, pp.489-500, Taylor and Francis, CRC Press, USA.

Ringelstein, O. (2015) 'Now we can shower with rain water', GWF, Wasser-Abwasser, Vol. 156, No. 156, pp.58-61. 
Rodríguez, M.I., Cuevas, M.M., Martínez, G. and Moreno, B. (2014) 'Planning criteria for water sensitive urban design', WIT Transactions on Ecology and the Environment, Vol. 191, No. 191, pp.1579-1591.

Rubinato, M., Shucksmith, J., Saul, A.J. and Shepherd, W. (2013) 'Comparison between InfoWorks hydraulic results and a physical model of an urban drainage system', Water Sci. Technol., Vol. 68, No. 2, pp.372-379, DOI: 10.2166/wst.2013.254.

Sage, J., Berthier, E. and Gromaire, M.C. (2015) 'Stormwater management criteria for on-site pollution control: a comparative assessment of international practices', Environmental Management, Vol. 56, No. 1, pp.66-80.

Saunders, N.J. and Peirson, W.L. (2013) 'Climate change adaptation of urban water management systems in the wet/dry tropics', Australian Journal of Water Resources, Vol. 17, No. 2, pp.180-192.

Sedlak, D. (2014) Water 4.0: The Past, Present and Future of the World's Most Vital Resource, Yale University Press, New Haven, CT.

Sitzenfrei, R., Möderl, M. and Rauch, W. (2013) 'Assessing the impact of transitions from centralised to decentralised water solutions on existing infrastructures - integrated city-scale analysis with VIBe', Water Research, Vol. 47, No. 20, pp.7251-7263, DOI: 10.1016/j.watres. 2013.10.038.

Speak, A.F., Rothwell, J.J., Lindley, S.J. and Smith, C.L. (2013) 'Rainwater runoff retention on an aged intensive green roof', Science of the Total Environment, September, Vols. 461-462, pp.28-38.

Staufer, P. and Pinnekamp, J. (2008) 'In situ measurements of shear stresses of a flushing wave in a circular sewer using ultrasound', Water Sci. Technol., Vol. 57, No. 9, pp.1363-1368, DOI: $10.2166 /$ wst.2008.300.

Stephenson, D. (1999) 'Demand management theory', Water, Vol. 25, No. 25, pp.115-122.

Stratigea, D. and Makropoulos, C. (2015) 'Balancing water demand reduction and rainfall runoff minimisation: modelling green roofs, rainwater harvesting and greywater reuse systems', Water Science and Technology: Water Supply, Vol. 15, No. 2, pp.248-255.

Thomas, R.B., Kirisits, M.J., Lye, D.J. and Kinney, K.A. (2014) 'Rainwater harvesting in the United States: a survey of common system practices', Journal of Cleaner Production, Vol. 75, pp.166-173 [online] https://doi.org/10.1016/j.jclepro.2014.03.073.

Ursino, N. (2016) 'Risk analysis approach to rainwater harvesting systems', Water, Vol. 8, No. 8, p.337.

Ursino, N. and Grisi, A. (2017) 'Reliability and efficiency of rainwater harvesting systems under different climatic and operational scenarios', International Journal of Sustainable Development and Planning, Vol. 12, No. 1, pp.194-199, DOI: 10.2495/SDP-V12-N1-194199.

Vallès-Casas, M., March, H. and Saurí, D. (2016) 'Decentralized and user-led approaches to rainwater harvesting and greywater recycling: the case of Sant Cugat del Vallès, Barcelona, Spain', Built Environment, Vol. 42, No. 2, pp.243-257.

Wella-Hewage, C.S., Hewa, G.A. and Pezzaniti, D. (2016) 'Can water sensitive urban design systems help to preserve natural channel-forming flow regimes in an urbanised catchment?', Water Science and Technology, Vol. 73, No. 1, pp.78-87, DOI: 10.2166/wst.2015.464.

Willems, P. (2013) 'Revision of urban drainage design rules after assessment of climate change impacts on precipitation extremes at Uccle, Belgium', Journal of Hydrology, 24 July, Vol. 496, pp.166-177, https://doi.org/10.1016/j.jhydrol.2013.05.037.

Williams, C. (2007) 'Saving the rain is a global objective', Water and Wastewater International, Vol. 22, No. 6, pp.37-38.

Wilson, C.E., Hunt, W.F., Winston, R.J. and Smith, P. (2014) 'Assessment of a rainwater harvesting system for pollutant mitigation at a commercial location in Raleigh, NC, USA', Water Science and Technology: Water Supply, Vol. 14, No. 2, pp.283-290, DOI: 10.2166/ ws.2013.200. 
Xu, W., Fletcher, T., Duncan, H., Bergmann, D., Breman, J. and Burns, M. (2018) 'Improving the multi-objective performance of rainwater harvesting systems using real-time control technology', Water, Vol. 10, No. 2, p.147.

Yannopoulos, S., Antoniou, G., Kaiafa-Saropoulou, M. and Angelakis, A.N. (2017) 'Historical development of rainwater harvesting and use in Hellas: a preliminary review', Water Science and Technology: Water Supply, Vol. 17, No. 4, DOI: 10.2166/ws.2016.200.

Yio, M.H.N., Stovin, V., Werdin, J. and Vesuviano, G. (2013) 'Experimental analysis of green roof substrate detention characteristics', Water Science and Technology, Vol. 68, No. 7, pp.1477-1486.

Zhou, Q., Panduro, T.E., Thorsen, B.J. and Arnbjerg-Nielsen, K. (2013) 'Adaption to extreme rainfall with open urban drainage system: an integrated hydrological cost-benefit analysis', Environmental Management, Vol. 51, No. 3, pp.586-601. 